ISSN 1392-3196 / e-ISSN 2335-8947

Zemdirbyste-Agriculture, vol. 102, No. 4 (2015), p. 411-416

DOI 10.13080/z-a.2015.102.052

\title{
New non-chemical postharvest technologies reducing berry contamination
}

\author{
Neringa RASIUKEVIČIŪTĖ ${ }^{1}$, Alma VALIUŠKAITE ${ }^{1}$, Nobertas USELIS ${ }^{1}$, \\ Loreta BUSKIENE ${ }^{1}$, Jonas VIŠKELIS ${ }^{1}$, Živile LUKŠIENE ${ }^{2}$ \\ ${ }^{1}$ Institute of Horticulture, Lithuanian Research Centre for Agriculture and Forestry \\ Kauno 30, Babtai, Kaunas distr., Lithuania \\ E-mail: n.rasiukeviciute@1sdi.lt \\ ${ }^{2}$ Institute of Applied Research, Vilnius University \\ Saulètekio 10, Vilnius, Lithuania
}

\begin{abstract}
One of the most important postharvest diseases of strawberry and raspberry is grey mould, caused by Botrytis cinerea Pers.: Fr. New non-chemical food safety technologies reducing berry rots and extending storage time were tested. Photosensitization is an innovative method for inhibition of pathogens in berry and is based on the interaction of light $\left(\lambda=400 \mathrm{~nm}, 20 \mathrm{~mW} \mathrm{~cm}^{-2}\right)$ and photoactive compound (chlorophyllin derivative). The aim of this study was to evaluate the effect of the chlorophyllin-based photosensitization on the reduction of grey mould (B. cinerea) in postharvest strawberry and raspberry fruits. The berries were soaked in a treatment solution for 1 hour and then exposed to prototype (light) for 30 minutes. The obtained data indicated that chlorophyllin derivative inhibited grey mould infection on fruits. The infection of $B$. cinerea in strawberries after a 6-day storage decreased by $8 \%$ and in raspberries after 1-day storage it decreased by $3 \%$. The chlorophyllin had no impact on the visual quality and nutritional properties of strawberries and raspberries.
\end{abstract}

Key words: Botrytis cinerea, chlorophyllin derivative, photosensitization, raspberry, strawberry.

\section{Introduction}

Raspberries and strawberries, which are consumed fresh and processed, are the most popular soft fruits in the world and Lithuania (Uselis et al., 2008). Berries contain many vitamins, minerals, and a high content of phenolic compounds, other antioxidants and bioactive compounds (Viskelis et al., 2010; Bobinaitè et al., 2013). Phenolic compounds and anthocyanins are regarded as healthy, natural and functional components in human nutrition (Bobinaite et al., 2012; Luksiene etal., 2013).

Fungal and bacterial infections are the main reason for $50 \%$ or greater yield losses of soft fruits during postharvest storage (Botrytis..., 2007). The initial strategy for reducing postharvest losses is appropriate agrotechnical handling and chemical pesticides (Droby, Lichter, 2007; Droby et al., 2009).

One of the most important postharvest diseases of soft fruits is grey mould caused by Botrytis cinerea Pers.: Fr., which results in a yield reduction ranging from $15 \%$ to $50 \%$ (Staats et al., 2005; Droby, Lichter, 2007). The $B$. cinerea infects more than 200 host plants worldwide (Staats et al., 2005). Symptoms of grey mould vary depending on the host, infection starts through flowers, various injuries, cracks and cuts. The pathogen has the capability to remain quiescent in unripe tissue and disease symptoms develop in ripe fruit. In berries, grey mould causes preharvest and postharvest fruit losses (Staats et al., 2005; Botrytis..., 2007; Droby et al., 2009).
Conventionally grey mould (B. cinerea) in strawberries is controlled by routine applications of fungicides once a week during flowering. Significant amounts of pesticides against diseases are used during the growing season of strawberries (Staats et al., 2005; Botrytis..., 2007). This type of application has become unacceptable because the inadequate usage of pesticides leads to the pathogen resistance (Botrytis..., 2007; Droby et al., 2009). Using forecasting models, applications of fungicides are made only when the model shows favourable conditions for $B$. cinerea development (Valiuškaitė et al., 2010; Rasiukevičiūtè et al., 2013). The cultivation of strawberries on plastic mulch had a positive effect on reducing fruit rot (Uselis et al., 2008). It is very expensive to use chemical fungicides and they have a negative impact on human health and environment (Botrytis..., 2007; Luksiene, Zukauskas, 2009).

Photosensitization is an innovative method for eliminating fruit pathogens based on simultaneous use of light and a photosensitizer. Chlorophyllin-photoactive compound is known as a photosensitizer, it is a watersoluble food additive (E140), and chlorophyllin derivative is safe as well (Luksiene, 2005; Luksiene, Zukauskas, 2009; Luksiene et al., 2010; Luksiene, Brovko, 2013; Luksiene, 2014). The data presented in Luksiene and Paskeviciute (2011) research clearly indicated that food pathogens and moulds in lab-scale experiments were 
effectively removed from the surface of strawberries. The aim of this study was to evaluate the effect of the chlorophyllin-based photosensitization on the reduction of grey mould (B. cinerea) in postharvest strawberry and raspberry fruits.

\section{Materials and methods}

Experiments. The experimental protocol for chlorophyllin-based photosensitization decontamination of berries was elaborated in Vilnius University, Institute of Applied Research. The effect of the photosensitization of chlorophyllin derivative (Chld) ("Alfa Aesar", Germany) on decontamination of berries was investigated at the Institute of Horticulture, Lithuanian Research Centre for Agriculture and Forestry in 2012 and 2013. In the experiments, we evaluated the effect of postharvest photosensitization on strawberry (Fragaria $\times$ ananassa Duch.) cv. 'Darselect' and raspberry (Rubus idaeus L.) cv. 'Polka'. The illumination experiments and assessment of diseased fruit were conducted in the Laboratory of Plant Protection. The quality tests were done in the Laboratory of Biochemistry and Technology. The raspberry (August 2012) and strawberry (June 2013) fruit samples were collected in the experimental field of Institute of Horticulture. The experimental design of treatments is provided in Table 1.

Table 1. The experimental design of postharvest treatment of strawberries and raspberries

\begin{tabular}{|c|c|c|c|}
\hline No. & Treatment & $\begin{array}{c}\text { Treatment } \\
\text { abbreviation }\end{array}$ & Rate \\
\hline 1. & Untreated and not illuminated & control & - \\
\hline 2. & Treated with water solution of chlorophyllin derivative + illuminated by prototype & Chld & $1.5 \times 10^{-3} \mathrm{M}$ \\
\hline 3. & Treated with sterile distilled water + illuminated by prototype & water & - \\
\hline
\end{tabular}

Illumination. The LED-based light source prototype for photosensitization was constructed in the Institute of Applied Research of Vilnius University (Fig. 1 B). The InGaN light emitting diode (LED) array LZ1-00UA00 (LED Engine Inc., USA) was used as a source of the light. The source of the light consisted of an illumination chamber and a supply unit (Luksiene, Zukauskas, 2009; Luksiene, 2014). The berries used in the experiments were of the same maturity, size and free of physical damage. Visually healthy fruits were soaked in chlorophyllin derivative (Chld) or water solution for
1 hour. Dehumidified fruits were placed on a sterile tray in a chamber of light source and were exposed for 30 minutes ( $15 \mathrm{~min}$ one side and $15 \mathrm{~min}$ - the other side). LED-based prototype emitted light in the $\lambda=400 \mathrm{~nm}$ with the intensity of $20 \mathrm{~mW} \mathrm{~cm}^{-2}$ on the surface of fruits. The InGaN light emitting diodes in the prototype ranged from the top of the illumination chamber. The control treatment was not soaked in Chld or water and not illuminated. After treatment, fruits were stored in a climate chamber KBF720 ("Binder", German) at a temperature of $5-7^{\circ} \mathrm{C}$.
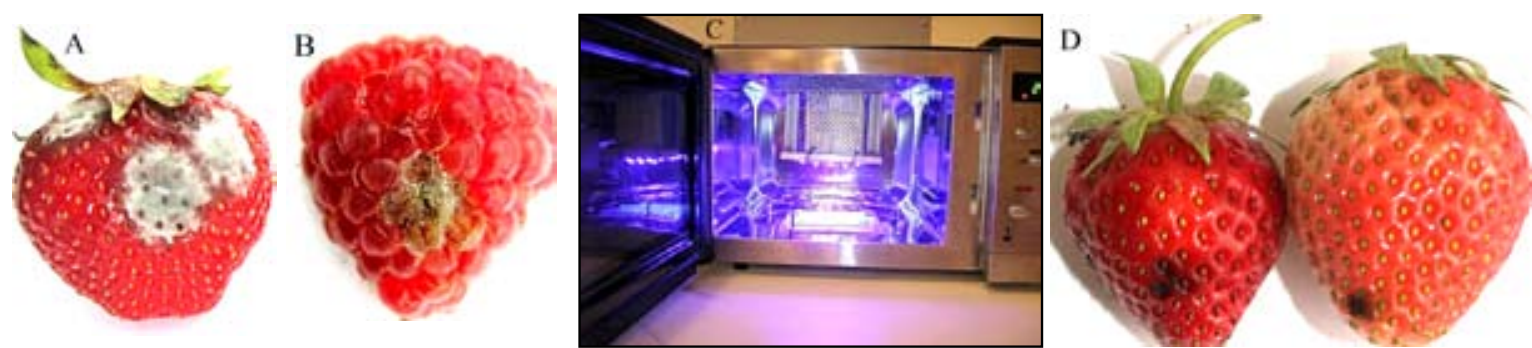

Figure 1. Strawberries and raspberries infected by Botrytis cinerea (control - untreated) (A, B), light source (illumination chamber) (C), strawberries after the application of chlorophyllin derivative and illumination (D)

The evaluation of $B$. cinerea decontamination efficiency. The effect of chlorophyllin derivative-based photosensitization on decontamination of $B$. cinerea was evaluated according to the EPPO standards PP 1/16(2) (EPPO, 1996). The B. cinerea frequency of occurrence (\%) was estimated by the percent ratio of the number of samples where the genus was detected to the total number of tested fruits (Gonzalez et al., 1999). The incidence of $B$. cinerea was calculated based on berry surface browning and/or presence of mycelium. Visually detected $B$. cinerea was proved microscopically. Disease incidence (\%) is the number of infected fruits per sample (Žemès ūkio augalų kenkejjai..., 2002). The assessments of strawberries were made until the $9^{\text {th }}$ day of storage and of raspberries until the $4^{\text {th }}$ day. One replication consisted of 50 fruits of strawberry and 90 fruits of raspberry with four replicates per treatment. For each replication, fruits were classified into healthy (visually without infection) and diseased (with disease symptoms).

Nutritional quality of strawberries. Berries were analysed immediately after treatment to find out if illumination and Chld had an influence on their appearance.

Firmness of strawberries was measured by a texture analyser TA.XTPlu ("Stable Micro Systems", England) and the data were processed by the program Texture Exponent. A flat head stainless cylindrical probe of $2 \mathrm{~mm}$ diameter was used for the penetration test. The speed of a probe was $1 \mathrm{~mm} \mathrm{~s}^{-1}$ the depth of the penetrated tissues was $10 \mathrm{~mm}$.

The colour coordinates $\left(\mathrm{L}^{*}, \mathrm{a}^{*}, \mathrm{~b}^{*}\right)$ in the CIEL*a*b* (CIEL*a*b* color scale, 1996) scale of the strawberry surface was measured with a spectrophotometer MiniScan XE Plus (HunterAssociates Laboratory Inc., USA). The $\mathrm{L}^{*}$ value indicates the ratio of white to black colour, $\mathrm{a}^{*}$ value indicates the ratio of red to green colour, and $b^{*}$ value indicates the ratio of yellow to blue colour. The chroma $\left(C^{*}=\left(a^{*} 2+b^{*} 2\right)^{1 / 2}\right)$ and hue angle $\left(\mathrm{h}^{\circ}=\arctan \left(\mathrm{b}^{*} / \mathrm{a}^{*}\right)\right)$ were also calculated (McGuiere, 1992).

The content of soluble solids in berry was measured with a digital refractometer Atago PAL 3 
(Atago Co. Ltd., Japan). Ascorbic acid (vitamin C) was determined by a titrimetric method using 2,6-dichlorphenolindophenol sodium salt solution (AOAC, 1990). The total quantity of phenolic compounds, expressed as a gallic acid equivalent, was determined spectrophotometrically (Slinkard, Singleton, 1997).

The antioxidant DPPH (2.2-diphenyl1-picrylhydrazyl hydrate) activity was evaluated spectrophotometrically by a Brand-Williams method. DPPH radical methanol solution $\left(2 \mathrm{~mL} 6 \times 10^{-5} \mathrm{M}\right)$ was mixed with $20 \mathrm{~mL}$ of strawberry extract. The results obtained at the absorption of $515 \mathrm{~nm}$ were recorded by a spectrophotometer Genesys-10 UV/Vis (Brand-Willians et al., 1995). The results were expressed as Trolox equivalents ( $\mu \mathrm{mol} 1 \mathrm{~g}^{-1}$ berry).

The amount of anthocyanins in berries was determined by a $\mathrm{pH}$ differential method and expressed as cyanidin-3-glucoside equivalents ( $\mathrm{mg} 100 \mathrm{~g}^{-1}$ ) (Giusti, Wrolstad, 2001). Anthocyanin concentration was calculated by the formula:

$$
\frac{\left(A_{510 \mathrm{pH} 1}-A_{700 \mathrm{pH} 1}\right)-\left(A_{510 \mathrm{pH} 4.5}-A_{700 \mathrm{pH} 4.5}\right)}{\varepsilon \cdot L} \cdot M W \cdot k,
$$

where $\varepsilon-$ molar absorption (the coefficient of molar extinction), $L$ - thickness of the test solution (cm), $M W$ - molecular weight of cyanidin-3-glucoside, $k$ - dilution factor, $A$-absorption. All measurements were carried out three times and the results were presented as mean.

Statistical analysis. The pathogens were identified according to the morphological traits, which were typical of the colonies (Vidhyasekaran, 2004; Botrytis..., 2007). The data were analysed with a module ANOVA of the software STATISTICA 7.0. The standard deviation was calculated and marked in a figure as bars.

\section{Results and discussion}

Postharvest diseases cause a great loss of fruits during the process of transportation and storage. Chemical fungicides are the main strategy for controlling postharvest losses (Sharma et al., 2009). Various studies of non-chemical treatments, including modified atmosphere with high $\mathrm{CO}_{2}$, volatile compounds, edible coatings, $\mathrm{UV}-\mathrm{C}$ and others, were conducted in order to prolong the postharvest period of soft fruits. Nigro et al. (2000) found that UV-C $254 \mathrm{~nm}$ reduces postharvest decay on strawberries. Neri et al. (2014) ran a test on thirty-five strawberry volatile organic compounds on $B$. cinerea in vitro and found that 14 compounds significantly influenced the conidial germination of $B$. cinerea. Tezotto-Uliana et al. (2014) ran a test on pre and post-harvest chitosan coating in order to prolong the shelf life of raspberries.

The data obtained in our previous study revealed that chlorophyllin-based treatment reduced food pathogen Listeria monocytogenes by 7-log in vitro (Luksiene et al., 2010). Luksiene and Brovko (2013) found that chlorophyllin reduced Listeria and Bacillus populations by $4.5-\log$ and $5-\log$ cycles, respectively. The data obtained in previous experiments clearly indicate that food pathogens can be easily destroyed by photosensitization on the surfaces of food products, also on strawberry fruits (Luksiene, 2005; Luksiene et al., 2010; Luksiene, Paskeviciute, 2011; Luksiene, Bovko, $2013)$. It is known that $B$. cinerea can rapidly adapt to the environment and develop resistance, but it is susceptible to photosensitization (Luksiene, 2005; Luksiene, Paskeviciute, 2011). Benzimidazoles fungicides were introduced for plant disease control in the 1960's, but within a few years resistance emerged (Kretschmer, Hahn, 2008; Debieu et al., 2013; Rodríguez et al., 2014). Our research was carried out to test the new nonchemical measures reducing $B$. cinerea on berry fruits. The photosensitization or volatile compound-based plant protection does not cause pathogen resistance (Neri et al., 2014; Rodríguez et al., 2014).

According to our analysis, treatment with photosensitization can reduce the contamination of berries with $B$. cinerea and prolong the disease-free period of fruits (Figs. 2-3). In our investigations, Botrytis cinerea was determined as only one causal agent of fruit rots. Experimental data revealed that 6 days after the Chld treatment, the number of Botrytis infected strawberries reduced by $8 \%$ and the number of disease-free strawberries increased by $6 \%$ compared with the control (Fig. 2). After 6 days of storage, in the Chld treatment there were $15 \%$ less Botrytis-infected strawberries compared with water treatment. After an 8-day storage, in the Chld treatment there were $20 \%$ and $5 \%$ more healthy fruits compared with the control and water treatment. In water treatment, the incidence of $B$. cinerea after a 6-day and 8-day storage was $17 \%$ and $16 \%$ higher compared to the Chld treatment (Fig. 2). The experimental results revealed that in Chld treatment there were less infected fruits $(8 \%$ and $13 \%$ ) compared to the control.

Experimental data showed that after a 6-day and 8-day storage in water treatment, the number of Botrytis infected strawberries increased by $9 \%$ and $3 \%$ in comparison with the control (Fig. 2). After a 6-day and 8 -day storage, the $B$. cinerea frequency of occurrence in Chld treatment was slightly lower ( $2 \%$ and $3.25 \%)$ compared with the control. In Chld treatment, after a 6-day and 8-day storage, $B$. cinerea frequency of occurrence was $4.25 \%$ and $2.5 \%$ lower compared with the water treatment. According to our experiments, we can conclude that in Chld treatment, after 6 days of storage, $B$. cinerea was reduced by $8 \%$.

Raspberries are highly perishable fruit. During storage, they lose firmness and change colour. The nutrition value of raspberries is very high, phenolic compounds are a major group of phytochemicals found in berries (Verde et al., 2013).

The experiments on raspberries revealed, that Chld treatment reduced $B$. cinerea by 3\% (after 1-day storage) and by $4 \%$ (after 3-day storage), respectively, compared with the control (Fig. 3). There were $6 \%$ (after 1-day storage) and 54\% (after 3-day storage) less infected fruits in Chld treatment, compared with water treatment. The comparison of Chld treatment with the control and water treatments revealed, that there were 3\% and 5\% more healthy fruits after 1-day of storage. Our experimental data indicated that after a 3-day of storage, in Chld treatment, there were 7\% and 55\% more healthy fruits, compared with the control and water treatment. After 1-day and 3-day storage B. cinerea frequency of occurrence in Chld treatment was lower (1\% and $2 \%)$ compared with the control. After 1 and 3 days, in Chld treatment $B$. cinerea frequency of occurrence was $2 \%$ and $13 \%$ lower compared with water treatment (Fig. 3). The analysis of both experiments showed the same tendency for raspberries and strawberries, - the Chld treatment reduced $B$. cinerea and water treatment stimulated it. 

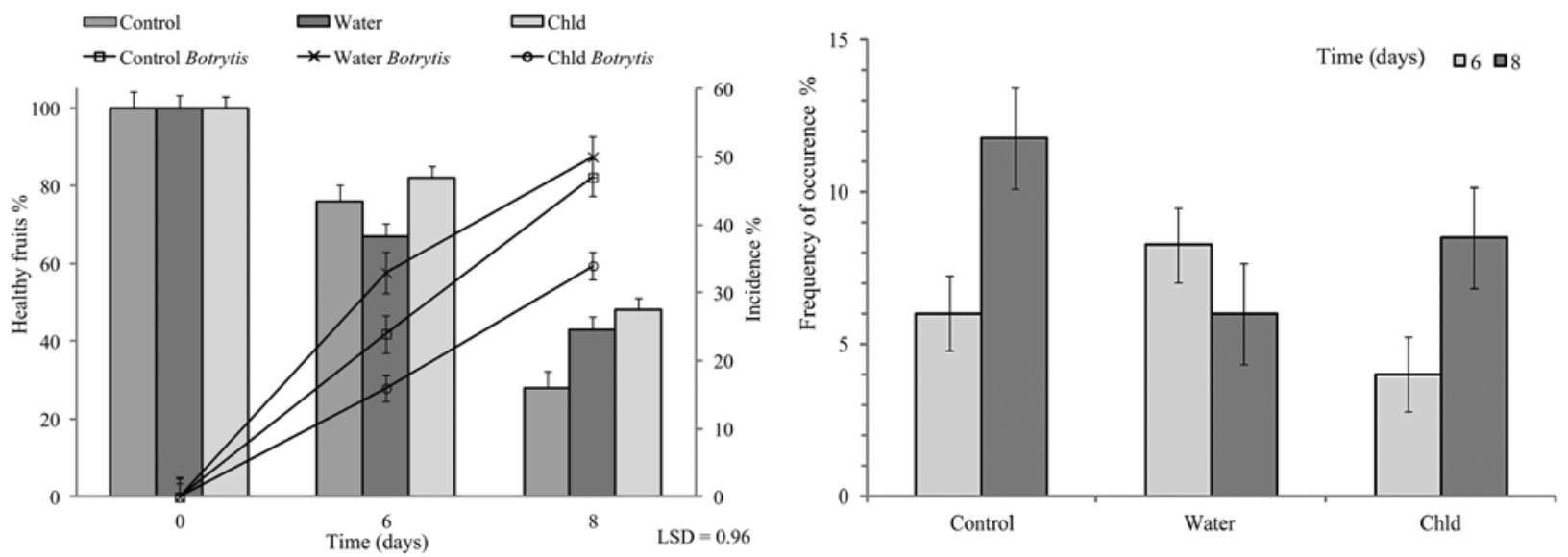

Figure 2. The inactivation of Botrytis cinerea by non-chemical chlorophyllin derivative (Chld) treatment in strawberries
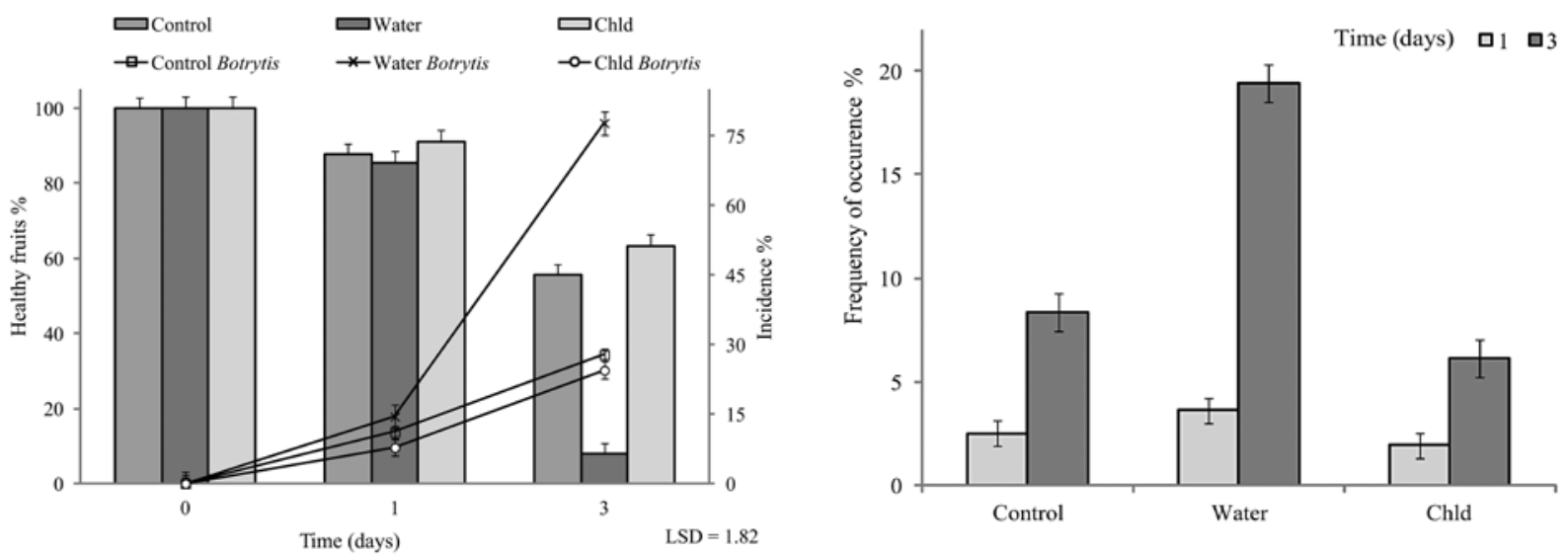

Figure 3. The inactivation of Botrytis cinerea by non-chemical chlorophyllin derivative (Chld) treatment in raspberries

The control of postharvest infections caused by $B$. cinerea relies on the preharvest applications. Nowadays chemical pesticides are major products used for applications against B. cinerea (Droby, Lichter, 2007; Droby et al., 2009). Due to the nontoxic properties of photosensitization, this treatment can be applied for microbial control as well (Luksiene et al., 2010). Recent studies of Tezotto-Uliana et al. (2014) showed that different chitosan concentrations inhibit the growth of pathogens by up to $88.9 \%$.

The amount of soluble solids, vitamin $\mathrm{C}$, total phenolic, anthocyanins content, antioxidant activity and firmness in strawberries were evaluated as well (Table 2). The results presented in Table 2 suggest that

the chemical composition and firmness of strawberries among the treatments varied a little, but the treatment itself did not have a statistically significant effect. The total phenolic compounds in the control strawberries was $273.7 \pm 8.8 \mathrm{mg} 100 \mathrm{~g}^{-1}$, whereas in the Chld-treated it

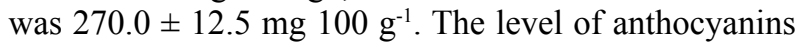
in strawberries after the Chld treatment was $158.83 \pm$

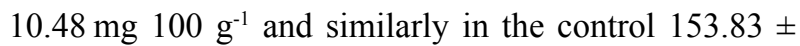
$8.28 \mathrm{mg} 100 \mathrm{~g} \mathrm{~g}^{-1}$. The data presented in Table 2 indicated that the average firmness of Chld-treated strawberries was $16.02 \pm 0.33 \mathrm{~N} \mathrm{~cm}^{-2}$.

The firmness of the control strawberries was 16.66 $\pm 0.55 \mathrm{~N} \mathrm{~cm}^{-2}$. The colour coordinates of strawberries, compared with the control treatment, showed a very

Table 2. The influence of non-chemical treatment on the colour and chemical composition of strawberries

\begin{tabular}{|c|c|c|c|c|c|c|}
\hline Treatment & $\begin{array}{l}\text { Fruit firmness } \\
\qquad \mathrm{N} \mathrm{cm}^{-2}\end{array}$ & $\begin{array}{c}\text { Ascorbic } \\
\text { acid } \\
\mathrm{mg} \%\end{array}$ & $\begin{array}{c}\text { Anthocyanins } \\
\text { mg } 100 \mathrm{~g}\end{array}$ & $\begin{array}{c}\text { Soluble solids } \\
\%\end{array}$ & $\begin{array}{c}\text { Total phenolic } \\
\text { compounds } \\
\text { mg } 100 \mathrm{~g}^{-1}\end{array}$ & $\begin{array}{l}\text { DPPH } \mu \text { mol } \\
1 \mathrm{~g}^{-1} \text { berries }\end{array}$ \\
\hline Control & $16.66 \pm 0.55$ & $70.3 \pm 1.2$ & $153.83 \pm 8.28$ & $10.9 \pm 0.2$ & $273.7 \pm 8.8$ & $14.85 \pm 0.14$ \\
\hline Chlorophyllin derivative (Chld) & $16.02 \pm 0.33$ & $70.7 \pm 2.5$ & $158.83 \pm 10.48$ & $10.7 \pm 0.2$ & $270.0 \pm 12.5$ & $14.74 \pm 0.06$ \\
\hline \multicolumn{7}{|c|}{ Colour parameters } \\
\hline & $\begin{array}{c}\mathrm{L}^{*} \\
\text { (lightness) }\end{array}$ & $\begin{array}{c}\mathrm{C}^{*} \\
\text { (chroma) }\end{array}$ & $\begin{array}{c}\mathrm{h}^{\circ} \\
\text { (hue angle) }\end{array}$ & $\begin{array}{c}\mathrm{a}^{*} \\
(+ \text { redness })\end{array}$ & $\begin{array}{c}\mathrm{b}^{*} \\
(+ \text { yellowness })\end{array}$ \\
\hline \multicolumn{2}{|l|}{ Control } & $36.27 \pm 3.98$ & $38.58 \pm 3.00$ & $33.76 \pm 4.12$ & $31.93 \pm 1.86$ & $21.50 \pm 3.62$ \\
\hline \multicolumn{2}{|c|}{ Chlorophyllin derivative (Chld) } & $32.47 \pm 3.03$ & $38.01 \pm 4.22$ & $30.91 \pm 3.99$ & $32.44 \pm 2.84$ & $19.65 \pm 4.07$ \\
\hline
\end{tabular}

Note. The results are expressed as mean \pm standard deviation. 
slight, statistically insignificant difference as well, which led to the conclusion that the use of Chld did not have any influence on the colour of strawberries. Colour is the main indicator of fruit quality, which has an influence on the appearance and price (Luksiene et al., 2013).

In order to estimate specific changes of nutritional quality of raspberries, we evaluated the amount of ascorbic acid, total phenolic compounds, soluble solids, DPPH and flavonoids anthocyanins (Table 3). The raspberry fruit firmness depends on the variety, berry maturity, environmental conditions, processing, transportation and others factors (Verde et al., 2013). It was difficult to evaluate the influence of treatments on the disease incidence because raspberries are very fast perishable fruits (data are not shown).

Table 3. The influence of non-chemical treatment on the chemical composition of raspberries

\begin{tabular}{|c|c|c|c|c|c|}
\hline Treatment & $\begin{array}{c}\text { Ascorbic } \\
\text { acid } \\
\mathrm{mg} \%\end{array}$ & $\begin{array}{c}\text { Anthocyanins } \\
\text { mg } 100 \mathrm{~g}\end{array}$ & $\begin{array}{c}\text { Soluble solids } \\
\%\end{array}$ & $\begin{array}{l}\text { Total phenolic } \\
\text { compounds } \\
\text { mg } 100 \mathrm{~g}^{-1}\end{array}$ & $\begin{array}{l}\text { DPPH } \mu \text { mol } \\
1 \mathrm{~g}^{-1} \text { berries }\end{array}$ \\
\hline Control & $27.5 \pm 1.8$ & $81.4 \pm 5.8$ & $9.8 \pm 0.3$ & $311.4 \pm 9.8$ & $18.8 \pm 2.2$ \\
\hline Chlorophyllin derivative (Chld) & $27.7 \pm 1.7$ & $81.0 \pm 4.7$ & $9.6 \pm 0.4$ & $314.6 \pm 11.5$ & $18.1 \pm 2.6$ \\
\hline
\end{tabular}

Note. The results are expressed as mean \pm standard deviation.

Concerning ascorbic acid content, total anthocyanin and soluble solids, the photosensitization treatment had no impact on their amount in treated raspberries. The amount of total phenolic compounds in raspberries in the control treatment was $311.4 \pm 9.8 \mathrm{mg}$ $100 \mathrm{~g}^{-1}$, similar results were obtained in the Chld-treated

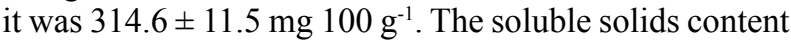
in the Chld-treated was $9.8 \pm 0.3 \%$, which is similar to the control $9.6 \pm 0.4 \%$. According to our investigation, no significant colour changes were detected in the treated raspberries (data not shown) in comparison with the control. Based on our experiments, we can conclude that Chld did not affect the appearance and nutritional value of strawberries and raspberries.

\section{Conclusions}

1. The chlorophyllin derivative-based photosensitization is an innovative postharvest treatment for the inhibition of Botrytis cinerea on strawberries and raspberries without any negative influence on the colour, antioxidant activity and phenolic compounds.

2 . The chlorophyllin derivative-based photosensitization reduced the contamination of strawberries with $B$. cinerea by $8 \%$ (after a 6-day storage) and that of raspberries by $3 \%$ (after 1-day storage).

3. Photosensitization has potential as a nonchemical plant protection tool, which could be used for the development of new plant protection technologies in agriculture.

\section{Acknowledgments}

The Lithuanian Council of Science (SVE02/2012) supported this study financially.

Received 17062015

Accepted 25092015

\section{References}

AOAC Official Methods of Analysis. 1990. Vitamin C (ascorbic acid) in vitamin preparations and juices. Helrich K. (ed.). Association of Official Analytical Chemists, USA (15 $5^{\text {th }} \mathrm{ed}$.)

Bobinaitė R., Viškelis P., Venskutonis P. R. 2012. Variation of total phenolics, anthocyanins, ellagic acid and radical scavenging capacity in various raspberry (Rubus spp.) cultivars. Food Chemistry, 132 (1): 1495-1501 http://dx.doi.org/10.1016/j.foodchem.2011.11.137
Bobinaitė R., Viškelis P., Šarkinas A., Venskutonis R. 2013. Phytochemical composition, antioxidant and antimicrobial properties of raspberry fruit, pulp, and marc extracts. CyTA - Journal of Food. 11 (4): 334-342 http://dx.doi.org/10.1080/19476337.2013.766265

Botrytis: biology, pathology and control. 2007. Elad Y. et al. (eds). Dordrecht. The Netherlands http://dx.doi.org/10.1007/978-1-4020-2626-3

Brand-Williams W., Cuvelier M. E., Berset C. 1995. Use of a free radical method to evaluate antioxidant activity. LWTFood Science and Technologv. 28: 25-30 http://dx.doi.org/10.1016/S0023-6438(95)80008-5

CIE L*a*b* Color Scale. 1996. HunterLab Applications Note, 8 (7): $1-4$

Debieu D., Bach J., Montesinos E., Fillinger S., Leroux P. 2013. Role of sterol 3-ketoreductase sensitivity in susceptibility to the fungicide fenhexamid in Botrytis cinerea and other phytopathogenic fungi. Pest Management Science, 69 (5): 642-651 http://dx.doi.org/10.1002/ps.3418

Droby S., Lichter A. 2007. Post-harvest Botrytis infection: etiology, development and management. Elad Y. et al. (eds.). Botrvtis: biologv. nathologv and control. n. 349-367 http://dx.doi.org/10.1007/978-1-4020-2626-3 19

Droby S., Wisniewski M., Macarisin D., Wilson C. 2009. Twenty years of postharvest biocontrol research: is it time for a new naradigm? Postharvest Biology and Technology, 52: 137-145 http://dx.doi.org/10.1016/j.postharvbio.2008.11.009

EPPO. 1996. Guideline on good plant protection practice: strawberry. OEPP/EPPO Bulletin. 26: 369-390 http://dx.doi.org/10.1111/j.1365-2338.1996.tb00601.x

Giusti M. M., Wrolstad R. E. 2001. Anthocyanins. Characterization and measurement with UV-visible spectroscopy. Wrolstad R. E. (ed.). Current protocols in food analytical chemistry, F1.2.1-F1.2.13

Gonzalez H. H. L., Martinez E. J., Pacin A., Resnik S. L. 1999. Relationship between Fusarium graminearum and Alternaria alternata contamination and deoxynivalenol occurrence of Argentinian durum wheat. Mycopathologia, 144: $97-102$ http://dx.doi.org/10.1023/A:1007020822134

Kretschmer M., Hahn M. 2008. Fungicide resistance and genetic diversity of Botrytis cinerea isolates from a vineyard in Germany. Journal of Plant Diseases and Protection, 115 (5): 214-219

Luksiene Z. 2005. New approach to inactivate harmful and pathogenic microorganisms: photosensitization. Food Technology and Biotechnology, 43: 411-418

Luksiene Z. 2014. Novel approach to control pathogenic and harmful microorganisms in nonthermal way: photosensitization. Boziaris I. S. (ed.). Novel food preservation and microbial assessment techniques. p. 184-217 http://dx.doi.org/10.1201/b16758-9

Luksiene Z., Brovko L. 2013. Antibacterial photosensitizationbased treatment for food safety. Food Engineering Reviews, 5(4): 185-199

http://dx.doi.org/10.1007/s12393-013-9070-7 
Luksiene Z., Paskeviciute E. 2011. Novel approach to the microbial decontamination of strawberries: chlorophyllinbased photosensitization. Journal of Applied Microbiology, 110: $1274-1283$

http://dx.doi.org/10.1111/j.1365-2672.2011.04986.x

Luksiene Z., Zukauskas A. 2009. Prospects of photosensitization in control of pathogenic and harmful microorganisms. Journal of Applied Microbiologv. 107: 1415-1424 http://dx.doi.org/10.1111/j.1365-2672.2009.04341.x

Luksiene Z., Buchovec I., Paskeviciute E. 2010. Inactivation of several strains of Listeria monocytogenes attached to the surface of packaging material by Na-chlorophyllinbased photosensitization. Journal of Photochemistry and Photobiology B: Biology. 101 (3): 326-331 http://dx.doi.org/10.1016/j.jphotobiol.2010.08.002

Luksiene Z., Buchovec I., Viskelis P. 2013. Impact of highpower pulsed light on microbial contamination, health promoting components and shelf life of strawberries. Food Technology and Biotechnology, 51 (2): 284-292

McGuiere R. G. 1992. Reporting of objective color measurements. HortScience, 27 (12): 1254-1255

Neri F., Cappellin L., Spadoni A., Cameldi I., Alarcon A. A., Aprea E., Romano A., Gasperi F., Biasioli F. 2014. Role of strawberry volatile organic compounds in the development of Botrvtis cinerea infection. Plant Pathology, 64 (3): 709-717 http://dx.doi.org/10.1111/ppa.12287

Nigro F., Ippolito A., Lattanzio V., Di Venere D., Salerno M. 2000. Effect of ultraviolet-C light on postharvest decay of strawberry. Journal of Plant Pathology, 82 (1): 29-37

Rasiukevičiūtè N., Valiuškaitè A., Survilienè-Radzevičè E., Supronienè S. 2013. Investigation of Botrytis cinerea risk forecasting model in strawberries. Proceedings of Latvian Academy of Science, Section B. Natural, Exact and Applied Sciences. 67 (2): 195-198 http://dx.doi.org/10.2478/prolas-2013-0032

Rodríguez A., Acosta A., Rodríguez C. 2014. Fungicide resistance of Botrytis cinerea in tomato greenhouses in the Canary Islands and effectiveness of non-chemical treatments against gray mold. World Journal of Microbiology and Biotechnology, 30: 2397-2406 http://dx.doi.org/10.1007/s11274-014-1665-5
Sharma R. R., Singh D., Singh R. 2009. Biological control of postharvest diseases of fruits and vegetables by microbial antagonists: a review. Biological Control, 50: 205-221 http://dx.doi.org/10.1016/j.biocontrol.2009.05.001

Slinkard K., Singleton V. L. 1997. Total phenol analysis: automation and comparison with manual methods. American Journal of Enology and Viticulture, 28: 49-55

Staats M., van Baarlen P., van Kan J. A. 2005. Molecular phylogeny of the plant pathogenic genus Botrytis and the evolution of host specificity. Molecular Biology and Evolution. 22: 333-346 http://dx.doi.org/10.1093/molbev/msi020

Tezotto-Uliana J. V., Fargoni G. P., Geerdink G. M., Kluge R. A. 2014. Chitosan applications pre- or postharvest prolong raspberry shelf-life quality. Postharvest Biology and Technology, 91: 72-77 http://dx.doi.org/10.1016/j.postharvbio.2013.12.023

Uselis N., Lanauskas J., Zalatorius V., Duchovskis P., Brazaityte A., Urbonavičiūtè A. 2008. Evaluation of the methods of soil cultivation growing dessert strawberries in beds. Sodininkystè ir daržininkystè, 27 (2): 295-305

Valiuškaite A., Uselis N., Survilienè E. 2010. Investigation of iMETOS ${ }^{\circledR} \mathrm{sm}$ Botrytis sp. prediction model in strawberries. Sodininkystė ir daržininkystè, 29 (3): 1321(in Lithuanian)

Verde S. C., Trigo M. J., Sousa M. B., Ferreira A., Ramos A. C., Nunes I., Junqueira C., Melo R., Santos P. M.P., Botelho M. L. 2013. Effects of gamma radiation on raspberries: safety and quality issues. Journal of Toxicologv and Environmental Health. Part A. 76 (4-5): 291-303 http://dx.doi.org/10.1080/15287394.2013.757256

Vidhyasekaran P. 2004. Concise encyclopaedia of plant pathology. Binghamton, USA

Viskelis P., Rubinskienė M., Bobinaitè R., Dambrauskienė E. 2010. Bioactive compounds and antioxidant activity of small fruits in Lithuania. Journal of Food, Agriculture and Environment, 8 (3-4): 259-263

Žemès ūkio augalų kenkejjai, ligos ir jų apskaita. $2002 /$ compiled by Šurkus J., Gaurilčikienè I. Lithuanian Institute of Agriculture, 346 p. (in Lithuanian)

ISSN 1392-3196 / e-ISSN 2335-8947

Zemdirbyste-Agriculture, vol. 102, No. 4 (2015), p. 411-416

DOI $10.13080 /$ z-a.2015.102.052

\title{
Naujos necheminès technologijos, mažinančios uogu užkrèstumą jų laikymo metu
}

\author{
N. Rasiukevičiūte ${ }^{1}$, A. Valiuškaitè ${ }^{1}$, N. Uselis ${ }^{1}$, L. Buskienè ${ }^{1}$, J. Viškelis ${ }^{1}$, Ž. Lukšienè ${ }^{2}$ \\ ${ }^{1}$ Lietuvos agrarinių ir miškų mokslų centro Sodininkystès ir daržininkystès institutas \\ ${ }^{2}$ Vilniaus universiteto Taikomųjų mokslų institutas
}

\section{Santrauka}

Viena pagrindinių braškių ir aviečių uogų nuostolius sukeliančių ligų yra kekerinis puvinys (Botrytis cinerea Pers.: Fr.). Tirtos naujos necheminès maisto saugos technologijos, mažinančios uogų puvinius ir prailginčios jų vartojimo trukmę. Fotosensibilizacija yra novatoriškas metodas, taikomas slopinti puvinių patogenams uogose, pagrịstas matomos šviesos $\left(\lambda=400 \mathrm{~nm}, 20 \mathrm{~mW} \mathrm{~cm}^{-2}\right)$ ir fotojautrios medžiagos (chlorofilino darinio) sąveika. Tyrimo tikslas - taikant fotosensibilizacijos metodą įvertinti chlorofilino darinių įtaką mažinant aviečių ir braškių uogų užkrèstumą kekeriniu puviniu (B. cinerea) jų laikymo metu. Tyrimo metu uogos 1 val. buvo apdorojamos tiriamaisiais tirpalais ir 30 min. veiktos šviesos šaltiniu. Nustatyta, kad chlorofilinas laikymo metu mažina uogų užkrèstumą kekeriniu puviniu. Braškèse po 6 parų laikymo užkrèstumas sumažejo $8 \%$, o avietėse po 1 paros $-3 \%$. Chlorofilinas neturèjo įtakos braškių ir aviečių uogų išvaizdai bei maistinėms savybėms.

Reikšminiai žodžiai: avietès, Botrytis cinerea, braškès, chlorofilino dariniai, fotosensibilizacija. 